\title{
Strategi Pengembangan Wisata Bahari Desa Namu Guna Mendukung Perekonomian Masyarakat Sadar Wisata
}

\author{
Namu Marine Tourism Development Strategy to Supporting Communities Economy of \\ Tourism-aware
}

\author{
Ratna Diyah Palupi ${ }^{* 11}$, Ira ${ }^{1)}$, dan Risfandi ${ }^{2)}$ \\ 1)Progam Studi Oseanografi FPIK Universitas Halu Oleo, Kampus Hijau Bumi Tridharma Anduanohu Kendari \\ 2)Program Studi/Jurusan Agribisnis Perikanan FPIK Universitas Halu Oleo
}

\begin{abstract}
ABSTRAK
Konsekwensi sebuah desa menjadi desa wisata adalah adanya kesiapan mental masyarakat dan daya dukung lingkungan. Strategi yang benar akan dapat mewujudkan kesejahteraan masyarakat desa tersebut. Tujuan penelitian ini membuat strategi pengembangan wisata di Desa Namu dengan konsep masyarakat sadar wisata. Metode pengumpulan data menggunakan teknik sampling melalui wawancara dan penyebaran kuisioner dengan jumlah contoh 70 responden. Karekteristik kondisi dan potensi wisata dianalisis dengan supply-demand. Analisis demand digunakan untuk mngenali pola permintaan pengunjung. Kedua analisis tersebut digunakan sebagai bahan rujukan strategi pengembangan, yaitu menggunakan strengths, weaknesses, opportunities, and threats (SWOT). Berdasarkan Internal Factor Analysis Summary (IFAS), faktor internal yang menjadi kekuatan Desa Namu adalah keindahan panorama desa alami yang disertai pemandangan laut sekaligus air terjun merupakan kekuatan utama desa Namu sebagai tujuan wisata. Kelemahan terbesar adalah ketidaksiapan warga secara ekonomi sehingga wisata namu kurang menggerakkan perekonomian masyarakat. External Factor Analysis Summary (EFAS) yang menjadi peluang sebagai keberpihakan pemerintah mulai dari kapupaten bahkan sampai tingkat nasional memungkinkan wisata Namu dapat dikembangkan. Akan tetapi ancaman yang patut diwaspadai datang dari investor luar yang dikhawatirkan dapat mengurangi peran masyarakat desa untuk meningkatkan perekonomiannya. Berdasarkan analisis IFAS da EFAS strategi pengembangan wisata Desa Namu adalah mempertahankan dan meningkatkan mutu obyek wisata, koordinasi dengan pemerintah (dinas terkait) dan masyarakat dalam pengembangan daya tarik wisata, menjalin kerjasama dengan pelaku bisnis di bidang pemasaran (promosi) dan transportasi, meningkatkan kemampuan masyarakat dengan pelatihan, terutama di bidang pariwisata, pemberadayaan masyarakat untuk berwirausaha hasil olahan produk perikanan dan cinderamata, perlu adanya pengelolaan sampah yang terpadu di Desa Namu, khususnya di masing-masing obyek wisata.
\end{abstract}

Kata kunci: Desa Namu, perekonomian masyarakat, SWOT, wisata

\section{ABSTRACT}

The consequence of tourist village is the community's psychology and environmental carrying capacity. Good strategy will be able to realize the welfare of the village community. The purpose of this study is to make a tourism development strategy in the Namu Village. Methods of data collection using sampling techniques through interviews and questionnaires with a total samples of 70 respondents. Characteristics of tourism conditions and potential are analyzed by supply-demand. While demand analysis is used to recognize the pattern of visitor demand. Both of these analyzes are used as reference materials for development strategies by strengths, weaknesses, opportunities, and threats SWOT analyzed. Furthermore, based on the Internal Factor Analysis Summary (IFAS), the beauty of Namu and the waterfall become the main attraction for tourist destination. On the other side the disadvantage is the unpreparedness of the Namu village community make them not enough in economically. External Factor Analysis Summary (EFAS), partisanship of the government enable for Namu to be developing in marine

\footnotetext{
*) Korespondensi:

Kampus Hijau Bumi Tridharma Anduanohu, Kendari 93232; email: pratna97@yahoo.com; Hp 082193134350
} 
tourism. However the threats was come from outside investor which can reduce the role of the community to improve their economy. Based on the analysis of IFAS and EFAS, the Namu Village's tourism development strategy is to improve the quality of tourism objects, increasing the role of the government, looking for investors especially in the transportation sector, improve community capacity. For instance manufacture of fishery products, souvenirs, and culinary. Finally safeguard ecosystems through waste management.

Key words: community economy, Namu village, SWOT, tourism

\section{PENDAHULUAN}

Prospek industri pariwisata di Indonesia sangat besar dan menjanjikan, mengingat negara Indonesia memiliki kekayaan alam yang melimpah. Pariwisata adalah segala kegiatan dalam masyarakat yang berhubungan dengan wisatawan (Soekadijo, 2001). Sektor pariwisata memberikan kontribusi yang cukup besar untuk Produk Domestik Bruto (PDB) nasional. Pariwisata menyumbang PDB sekitar 4,1\% secara langsung dan secara tidak langsung $9 \%$. Sektor pariwisata juga mampu bertahan menghadapi tekanan badai krisis global. Melalui program visit Indonesia Year 2019, sektor pariwisata berhasil menjaring dan mendatangkan wisatawan mancanegara 6,5 juta orang setara devisa USD 7.5 juta (Business news, 2010).

Konawe Selatan (Konsel) adalah salah satu kabupaten di provinsi Sulawesi Tenggara (Sultra) yang berasal dari hasil pemekaran Kabupaten Kendari yang disahkan dengan UU No. 4 Tahun 2003 tanggal 25 Februari 2003. Dengan diberlakukannya UU No. 23 Tahun 2014 tentang Pemerintahan Daerah dan UU No. 33 Tahun 2004 tentang perimbangan keuangan pusat dan pemerintahan daerah yang memberikan kewenangan lebih luas pada Pemerintah Daerah untuk mengelola wilayahnya. Hal ini telah membawa implikasi semakin besarnya tanggungjawab dan tuntutan untuk menggali dan mengembangkan seluruh potensi sumber daya yang dimiliki daerah dalam rangka menopang perjalanan pembangunan di daerah. Pemerintah daerah Konsel terus menggarap potensi wisata di desa-desa untuk mendongkrak perekonomian masyarakatnya. Pemerintah menyadari besarnya potensi kepariwisataan di daerah sehingga berusaha menggali, mengembangkan, serta membangun aset obyek dan daya tarik wisata, yang merupakan modal awal untuk bangkitnya kegiatan pariwisata. Keputusan ini ditindaklanjuti dengan memikirkan, mengusahakan, serta membenahi potensi obyek dan daya tarik wisata.
Desa Namu merupakan salah satu desa yang berada di wilayah administratif Kecamatan Laonti, Kabupaten Konawe Selatan. Desa ini merupakan hasil Pemekaran Desa Sangi-Sangi Kecamatan Moramo Kabupaten Dati Dua Kendari. Kondisi alamnya yang masih terjaga kealamiannya dan menarik, dimana ada perpaduan antara pemandangan alam laut dan hutan, membuat Desa ini di tahun 2017 dicanangkan sebagai salah satu desa wisata. Hal tersebut sebagai tindak lanjut dari hasil kunjungan Dewan Pertimbangan Presiden (Watimpres) ke Desa Namu, sehingga memasukkan Desa Namu sebagai salah satu destinasi wisata nasional dan telah disetujui oleh Presiden RI.

Desa wisata adalah suatu kawasan pedesaan yang menawarkan keseluruhan suasana yang mencerminkan keaslian perdesaan baik dari kehidupan sosial ekonomi, sosial budaya, adat istiadat, keseharian, memiliki arsitektur bangunan dan struktur tata ruang desa yang khas, atau kegiatan perekonomian unik dan menarik, serta mempunyai potensi untuk dikembangkannya berbagai komponen kepariwisataan, misalnya atraksi, akomodasi, makanan-minuman, dan kebutuhan wisata lainnya (Pariwisata Inti Rakyat (PIR) dalam Hadiwijoyo, 2012). Desa wisata Namu memiliki beberapa obyek wisata yang menarik yaitu wisata pantai, wisata bawah air, wisata air terjun, dan wisata hutan. Oleh karena itu perlu dilakukan penelitian mengenai strategi pengembangan wisata bahari Desa Namu.

\section{METODE PENELITIAN}

Lokasi penelitian berada di Desa Namu Kecamatan Laonti Kabupaten Konawe Selatan Propinsi Sulawesi Tenggara. Pengumpulan data dilakukan selama kurang lebih satu bulan, yaitu bulan Juni 2018 bersamaan dengan kegiatan pengabdian kepada msyarakat KKN-PPM.

Contoh masyarakat sebagai responden dibagi menjadi tiga kelompok yaitu masyarakat nelayan, masyarakat yang bergerak disektor pariwisata (pemilik homestay), dan masyarakat non 
nelayan dan non pariwisata (PNS, swasta, petani, dan pengunjung wisata di luar Desa Namu). Jumlah total contoh 70 orang yang terdiri dari 30 orang nelayan, masyarakat yang bergerak disektor pariwisata 15 orang, serta masyarakat non nelayan dan non pariwisata 25 orang.

\section{Metode Analisis}

Metode analisis yang digunakan meliputi analisis supply-demand, analisis demand, dan analisis SWOT. Analisis supply-demand bertujuan mengetahui karakteristik dan kondisi potensi wisata Desa Namu. Analisis demand untuk mengenali pola karakteristik permintaan pengunjung yang datang ke Desa Namu. Berdasarkan analisis tersebut dibuat strategi pengembangan desa wisata, yaitu dengan analisis SWOT. Analisis SWOT adalah instrumen perencanaan strategi klasik yang menggunakan kerangka kerja kekuatan dan kelemahan, pelung dan ancaman. Instrumen ini memberikan cara sederhana untuk memperkirakan cara terbaik dalam melaksanakan suatu strategi (Freddy, 2014)

Komponen supply dalam penelitian ini meliputi atraksi wisata, akomodasi, transportasi, infrastruktur, fasilitas pendukung. Sedangkan komponen demand meliputi segala sesuatu yang berhubungan dalam permintaan pariwisata, yaitu pengunjung dan masyarakat (Yoeti, 1996; Suwena, 2010). Analisis potensi dan masalah dilakukan dengan penjabaran dan penjelasan tentang potensi dan masalah yang terdapat di lokasi penelitian.

\section{HASIL DAN PEMBAHASAN}

\section{Karakteristik Desa Namu}

1. Kondisi Fisik

a. Batas administrasi

Secara administratif Desa Namu memiliki batas-batas wilayah: sisi Timur yang berhadapan langsung dengan Laut Banda dan pulau Buton Utara, sisi Selatan berdampingan langsung dengan Desa Batu Jaya, sisi utara dibatasi dengan Desa Malaringgi, sebelah Barat dibatasi dengan Kecamatan Kolono Timur.

b. Topografi dan luas wilayah Topografi ketinggian berupa dataran sedang, yaitu $21 \mathrm{~m}$ diatas permukaan laut. Luas wilayah $10,4 \mathrm{~km}^{2}$ atau mencapai 2,6\% dari keseluruhan luas Kecamatan Laonti.

c. Hidro-Oceanografi

Desa Namu dipengaruhi dua musim, yaitu Musim Barat dan Musim Timur. Musim
Barat terjadi bulan Oktober-Maret, dimana laut cenderung teduh. Musim Timur dimulai pada bulan April-September, dimana terjadi ombak besar.

2. Sosial budaya

a. Jumlah penduduk Desa Namu meliputi 477 jiwa yang terdiri dari 244 jiwa laki-laki dan 233 jiwa perempuan. Usia produktif mencapai kurang lebih 63\% dari jumlah total penduduk.

b. Mata pencaharian masyarakat adalah sebagian besar berprofesi nelayan dan sebagian kecil berkebun. Saat musim teduh (musim barat), masyarakat melakukan aktifitas menangkap ikan dan saat musim ombak besar (Musim Timur) masyarakat beralih kegiatan berkebun. Tanaman perkebunan terdiri dari cengkeh dan jambu mente.

3. Ekonomi

a. Potensi ekonomi yang ada di Desa Namu terdiri dari perikanan tangkap dan hasilhasil pertanian dan perkebunan berupa kelapa yang dibuat kopra, cengkeh, dan kacang mente.

b. Potensi hasil perikanan tangkap yang ada antara lain ikan kuwe/ikan putih, ikan tuna, ikan tongkol, ikan kakap, cumi-cumi, barakuda dan lain lain yang sebagian besar berupa ikan demersal atau ikan dasar

4. Sarana dan Prasarana

Desa Namu didukung dengan beberapa sarana dan prasarana seperti sarana pendidikan (dua Sekolah Dasar dan satu Sekolah Menengah Pertama), sarana peribadatan (tiga masjid), sarana kesehatan (satu polindes), serta sarana olahraga berupa lapangan voli pantai.

\section{Analisis supply demand pariwisata bahari}

1. Daya tarik wisata

a. Keindahan Alam

Desa Namu merupakan desa pesisir yang mempunyai bentang alam berupa pantai sekaligus perbukitan. Pemandangan matahari terbit yang menghadap langsung dari laut merupakan pemandangan eksotis bagi wisatawan untuk dapat berswafoto atau selfie (Gambar 1).

b. Wisata pantai

Wisata pantai terletak di lima titik yaitu Pantai Olo'a, Pantai Wiawia, Pantai Namu, Pantai Pasir Panjang dan Pantai Pole Pole Loa. Kelima pantai tersebut merupakan pantai yang sangat indah dan alami, serta 
ditumbuhi oleh pohon kelapa yang berjejer rapi (Gambar 1).

c. Wisata bawah laut

Pemandangan bawah laut yang jernih dan bersih dimana terdapat hamparan lamun dan ekosistem terumbu karang sehingga menarik wisatawan untuk diving, snorkling, berenang, bahkan wisata memancing. Spot diving terdapat di Dusun 3 dan 4 (Gambar 1)

d. Wisata Air terjun

Kawasan air terjun Pitundengga dikelilingi oleh hutan. Nama air terjun Pitundengga diperoleh dari jumlah tangga jatuhan air yang berjumlah tujuh buah (Gambar 1). Air terjun ini berjarak $1,5 \mathrm{~km}$ dari perkampungan Desa Namu. Ketinggian air terjun ini mencapai $10 \mathrm{~km}$ dengan pemandangan bebatuan dan pepohonan yang masih asri dan alami. Airnya tidak pernah kering meski di musim kemarau.
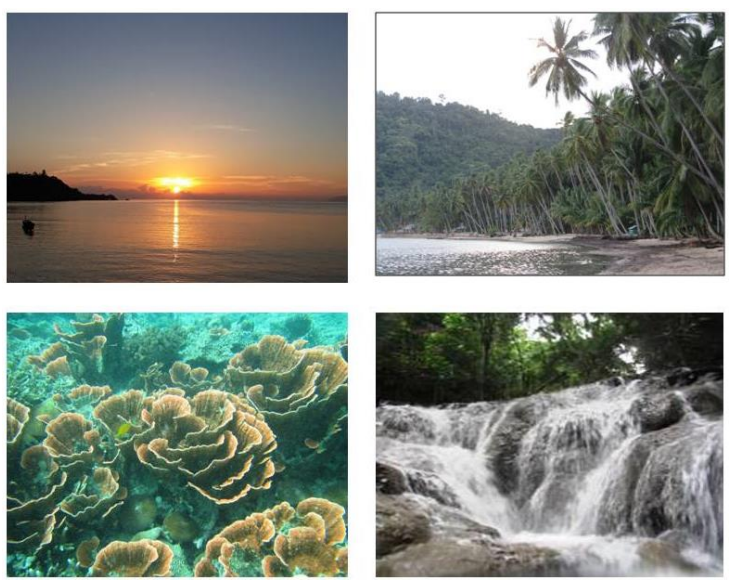

Gambar 1.Potensi wisata Desa Namu: sunrise, pesisir pantai Namu, pemandangan bawah laut, dan air

2. Sarana dan prasarana

a. Akomodasi (homestay)

Homestay adalah fasilitas penginapan bagi wisatawan yang ingin bermalan di Desa Namu. Fasilitas ini merupakan rumah warga yang disewakan kepada pengunjung. Sampai saat ini jumlah homestay 14 rumah, yang sebagian besar terdapat di Dusun 2. Tiap rumah dengan kapasitas empat orang (dua kamar) atau tanpa kamar dengan kapasitas lebih besar.

b. MCK atau toilet umum

MCK atau toilet umum dibangun di Dusun 2 yang merupakan gerbang wisata di desa ini. Toilet terdiri dari 4 kamar mandi dilengkapi dengan WC dan satu bak penampungan air. c. Tempat ibadah

Tempat ibadah berupa tiga masjid yang terletak di tiga dusun. Masyarakat Desa Namu mayoritas beragama islam.

d. Tempat olahraga

Tempat olahraga berupa lapangan voli pantai yang terletak di Dusun 2. Fasilitas ini baru dibangun Tahun 2018 dengan alokasi dana desa. Adanya fasilitas tersebut diharapkan menjadi salah satu daya tarik wisatawan yang hobi berolah raga untuk pergi ke Namu.

e. Air Bersih

Air bersih atau air tawar merupakan fasilitas dasar yang harus tersedia di kawasan wisata. Desa Namu memiliki sumber air tawar yang melimpah. Adanya air terjun dari perbukitan merupakan salah satu sumber air tawar. Di desa tersebut (Dusun 1 dan 2) terdapat aliran sungai yang menuju ke laut. Setiap rumah penduduk sudah dialiri air tawar dari pipa-pipa yang dipasang pada bak penampungan utama yang berada di atas gunung.

\section{Aksesibilitas}

Desa Namu masih berada dalam daratan Konawe Selatan, namun akses menuju desa ini hanya dapat ditempuh melalui transportasi laut. Hal tersebut dikarenakan akses jalur darat masih dalam tahap pengerjaan.

Terdapat dua alternatif yang dapat ditempuh ke Desa Namu. Pertama melalui jalur darat dari Kota Kendari menuju pelabuhan kayu (Desa Langgapulu Kec Kolono Timur) yang ditempuh kurang lebih dua jam perjalanan mobil, kemudian dilanjutkan dengan menggunakan kapal nelayan menuju Desa Namu 30-45 menit perjalanan (Gambar 2). Kapal-kapal warga dari Langgapulu disewa dengan tarif 250-500 ribu rupiah per kapal atau 25-30 ribu rupiah per orang.

Alternatif kedua, melalui jalur laut dari pelabuhan rakyat Kota Kendari langsung menuju Desa Namu. Akan tetapi belum ada kapal komersial yang berlayar secara reguler. Untuk itu pengunjung harus memesan dahulu apabila ingin berangkat langsung dari Kendari.

\section{Wisatawan}

a. Berdasarkan kuesioner yang diberikan kepada pengunjung di Desa Namu secara acak, diketahui bahwa usia pengunjung yang sering berkunjung ke Desa Namu berusia 21-45 tahun. 
Tabel 1. Potensi Desa Namu

\begin{tabular}{ll}
\hline \multicolumn{1}{c}{ Variabel } & \multicolumn{1}{c}{ Potensi } \\
\hline Daya Tarik wisata & - Desa namu memiliki lebih dari satu objek wisata yaitu wisata pantai (pantai pasir putih \\
& yang terletak di 5 titik yaitu pantai Olo'a, Pantai Wiawia, Pantai Namu, Pantai Pasir \\
& Panjang dan Pantai Pole Pole Loa), wisata bawah laut, wisata air terjun (Air Terjun \\
& Pitundengga), wisata cagar alam (hutan suaka margasatwa Tanjung Peropa) \\
& - Pemandangan alamnya masih sangat alami dan asri \\
\hline Aksesibilitas & - Desa Namu mudah diakses dengan transportasi laut \\
\hline Fasilitas & - Homestay yang disewakan kepada pengunjung/wisatawan \\
Kepariwisataan & - Gazebo sebagai tempat istrahat wisatawan \\
& - Sarana olaraga berupa lapangan bola voli pantai \\
& - MCK/Toilet umum di dekat lokasi wisata \\
& - Penyediaan air bersih \\
& - Tingkat keamananan sudah cukup baik \\
\hline Sumber Daya & - Sikap masyarakat yang ramah mendukung adanya pengembangan desa wisata \\
Manusia (SDM) & - Jumlah tenaga kerja usia produktif yang tersedia cukup memadai \\
\hline Informasi \& & - Keindahan beberapa obyek wisata di Desa Namu telah dikenal oleh masyarakat luas \\
Promosi & melalui internet dan media sosial \\
\hline
\end{tabular}

b. Kesan pengunjung/wisatawan adalah sebagian besar menyatakan masih perlu adanya perbaikan dan penambahan fasilitas.

c. Sebagian besar pengunjung atau wisatawan sangat berkesan dan ingin kembali lagi ke Desa Namu di lain waktu dan terkesan dengan keindahan alamnya dan keramah-tamahan penduduk Namu.
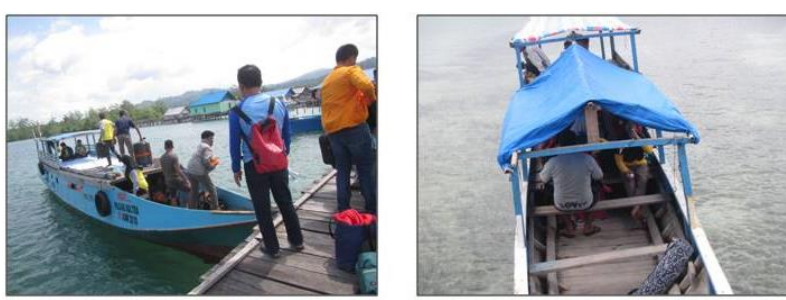

Gambar 2. Akses kapal nelayan yang digunakan pengunjung dari Langgapulu (kiri) dan Desa Namu, Dusun 2 (kanan)

\section{Analisis potensi}

Potensi yang ada di Desa Namu dapat dilihat pada Tabel 1.

\section{Analisis masalah}

Permasalahan yang ada di Desa Namu dapat dilihat pada Tabel 2.

\section{Analisis SWOT}

Berdasarkan analisis potensi dan masalah tersebut, selanjutnya dilakukan pemilahan berdasarkan kekuatan dan kelemahan, peluang dan ancaman terhadap pengembangan wisata Namu (Tabel 3, 4, dan 5).
Tabel 2. Permasalahan pengembangan wisata Desa Namu

\begin{tabular}{ll}
\hline \multicolumn{1}{c}{ Peubah } & \multicolumn{1}{c}{ Masalah } \\
\hline Daya Tarik & - Belum adanya cenderamata bagi \\
Wisata & pengunjung/wisatawan \\
Aksesibilitas & - Belum adanya angkutan darat yang \\
& menjangkau Desa Namu \\
\hline Fasilitas Ke- & - Belum adanya pengelolaan sampah \\
pariwisataan & di obyek wisata \\
& - Terbatasnya sinyal komunikasi \\
& - Listrik belum menyala 24 jam \\
\hline Sumber & - Belum adanya pemandu wisata \\
Daya & yang berpengalaman di bidang \\
Manusia & pariwisata \\
(SDM) & - Tidak adanya rumah makan atau \\
& restoran di obyek wisata \\
\hline Informasi \& & - Belum adanya pengelolaan terkait \\
Promosi & kepariwisataan \\
\hline
\end{tabular}

Berdasarkan IFAS dan EFAS maka susunan strategi pengembangan yang di dapatkan sebagai berikut:

1. Mempertahankan dan meningkatkan mutu objek wisata

2. Koordinasi dengan pemerintah (dinas terkait) dan masyarakat dalam pengembangan daya tarik wisata

3. Manfaatkan dukungan pemerintah kabupaten dan masyarakat untuk meningkatkan mutu obyek wisata

4. Jalin kerjasama dengan pelaku bisnis di bidang pemasaran (promosi) dan transportasi

5. Peningkatan kemampuan masyarakat dengan mengadakan pelatihan, terutama di bidang pariwisata. 
6. Pemberadayaan masyarakat untuk berwirausaha hasil olahan produk perikanan dan cinderamata

7. Meningkatkan kesadaran masyarakat tentang manfaat obyek wisata

8. Perlu adanya pengelolaan sampah yang terpadu di Desa Namu, khususnya dimasingmasing obyek wisata

9. Meningkatkan mutu SDM dan perbanyak fasilitas pendukung pariwisata

\section{Matrik Internal Faktor (IFAS)}

Tabel 3. Komponen internal SWOT

\begin{tabular}{cl}
\hline No & Kekuatan \\
\hline 1 & Daya tarik wisata yang menarik dan alami \\
2 & Terdapat lebih dari satu obyek wisata \\
3 & $\begin{array}{l}\text { Dukungan pemerintah untuk mengembangkan } \\
\text { sektor pariwisata cukup tinggi }\end{array}$ \\
4 & Keterbukaan masyarakat terhadap pengunjung \\
5 & Tersedianya homestay \\
6 & Tingkat keamanan umumnya cukup baik \\
7 & Tersedianya air bersih \\
\hline No & Kelemahan \\
\hline 1 & Tidak adanya pemandu wisata yang \\
& berpengalaman dibidang pariwisata \\
2 & Belum adanya akses darat langsung ke Desa \\
& Namu \\
3 & Belum adanya cenderamata bagi pengunjung/ \\
& wisatawan \\
4 & Sulitnya ditemui rumah makan hasil produk \\
& perikanan \\
5 & Belum adanya pengelolaan sampah secara \\
& terpadu \\
7 & Terbatasnya sinyal komunikasi \\
8 & Listrik belum menyala 24 jam \\
\hline
\end{tabular}

\section{Matrik Esternal Faktor (EFAS)}

Tabel 4. Komponen eksternal SWOT

\begin{tabular}{|c|c|}
\hline No & Peluang \\
\hline 1 & $\begin{array}{l}\text { Dengan adanya pemandu wisata dapat menarik } \\
\text { minat wisatawan untuk datang ke Desa Namu }\end{array}$ \\
\hline 2 & Potensi pengadaan cinderamata bagi pengunjung \\
\hline 3 & $\begin{array}{l}\text { Perkembangan dunia wisata yang mengarah ke } \\
\text { alam }\end{array}$ \\
\hline 4 & $\begin{array}{l}\text { Peluang kesempatan kerja dan berusaha bagi } \\
\text { masyarakat setempat }\end{array}$ \\
\hline 5 & $\begin{array}{l}\text { Kunjungan wisata dapat memberikan } \\
\text { pendapatan potensial bagi masyarakat }\end{array}$ \\
\hline No & Ancaman \\
\hline 1 & $\begin{array}{l}\text { Terdapat tempat wisata lain yang menjadi } \\
\text { pesaing }\end{array}$ \\
\hline 2 & $\begin{array}{l}\text { Pencemaran lingkungan dengan sampah- } \\
\text { sampah plastik makanan dibuang di sembarang } \\
\text { tempat }\end{array}$ \\
\hline 3 & Mudah masuk aliran sesat dan budaya asing \\
\hline 4 & Mudah masuknya peredaran narkoba \\
\hline
\end{tabular}

Lebih lanjut strategi pengelolaan tersebut haruslah memerhatikan aspek prioritas untuk mewujudkannya, yaitu jangka pendek, menengah, dan panjang. Riski et al. (2016) menyatakan bahwa pengembangan wisata bahari akan memberikan dampak multiplier effect terhadap perekonomian masyarakat lokal. Hal ini didorong dengan kemajuan media sosial yang sudah menjadi kebutuhan masyarakat. Konsep desa wisata dapat dijadikan sebagai pendorong perekonomian yang bersumber dari based community. Lebih lanjut Darsana et al. (2017) menyatakan penekanan desa wisata adalah pengelolaan langsung dari warga masyarakat lokal, dengan partisipasi aktif. Masyarakat terlibat mulai dari tahapan perencanaan hingga evaluasi. Oleh karena itu sangat dibutuhkan pemberdayaan masyarakat yang dimulai dari kajian sosial budaya, dukungan kalangan akademisi, dan pemerintah setempat.

Strategi pengembangan wisata desa Namu ini jika dibandingkan dengan kajian strategi pengembangan Pulau Kaledupa Kabupaten Wakatobi menunjukkan variabel hampir sama (Salim dan Purbani, 2015). Keduanya mengedepankan penekanan kepada pemerintah dan pelestarian lingkungan menjadi unsur yang penting dalam strategi pengelolaan.

\section{KESIMPULAN}

Pengembangan wisata di desa Namu lebih difokuskan kepada pemberdayaan masyarakat lokal, khususnya menjalankan roda perekonomian, yaitu memanfaatkan sumber daya yang ada dan mengoptimalkan peran pemerintah. Hal lainnya secara jangka panjang pengelolaan sampah harus menjadi fokus utama dalam pengelolaan.

\section{UCAPAN TERIMA KASIH}

Penulis mengucapkan terimakasih kepada DRPM Direktorat Jenderal Penguatan Riset dan Pengembangan Kemenristek Dikti RI atas Hibah KKN-PPM pendanaan Tahun 2018 berdasarkan No. Kontrak 487/UN29.20/PPM/2018. Kepada Kepala Desa Namu beserta jajarannya serta masyarakat Desa Namu yang telah membantu akomodasi dan fasilitas selama di lokasi. 
Tabel 5. Analisis SWOT Desa Namu

\begin{tabular}{|c|c|c|}
\hline Eksternal & $\begin{array}{l}\text { Strength (S ) / Kekuatan } \\
\text { - Daya tarik wisata yang } \\
\text { menarik dan alami } \\
\text { - } \text { Terdapat lebih dari satu } \\
\text { obyek wisata } \\
\text { - } \text { Dukungan pemerintah untuk } \\
\text { mengembangkan sektor } \\
\text { pariwisata cukup tinggi } \\
\text { - Keterbukaan masyarakat } \\
\text { - terhadap pengunjung } \\
\text { - Tersedianya homestay } \\
\text { - } \text { Tingkat keamanan umumnya } \\
\text { cukup baik }\end{array}$ & $\begin{array}{l}\text { Weakness }(\mathbf{W}) \text { / Kelemahan } \\
\text { - } \text { Tidak adanya pemandu wisata yang } \\
\text { berpengalaman dibidang pariwisata } \\
\text { - Belum adanya akses darat langsung } \\
\text { ke Desa Namu } \\
\text { - } \text { Belum adanya cenderamata bagi } \\
\text { pengunjung/wisatawan } \\
\text { - Sulitnya ditemui rumah makan hasil } \\
\text { produk perikanan } \\
\text { - } \text { Belum adanya pengelolaan sampah } \\
\text { - secara terpadu } \\
\text { - Terbatasnya sinyal komunikasi } \\
\text { - } \text { Listrik belum menyala } 24 \text { jam }\end{array}$ \\
\hline $\begin{array}{l}\quad \text { Opportunity (O) / Peluang } \\
\text { - } \\
\text { Dengan adanya pemandu wisata } \\
\text { dapat menarik minat wisatawan } \\
\text { untuk datang ke Desa Namu } \\
\text { - } \\
\text { Potensi pengadaan cinderamata bagi } \\
\text { pengunjung } \\
\text { - } \\
\text { Perkembangan dunia wisata yang } \\
\text { mengarah ke alam } \\
\text { - }\end{array}$ & \begin{tabular}{l}
\multicolumn{1}{c}{ Strategi SO } \\
1. Mempertahankan dan \\
meningkatkan mutu obyek \\
wisata (S1, S2, S3, S4, S5, \\
S6, S7, O3) \\
2. Koordinasi dengan peme- \\
rintah (dinas terkait) dan \\
masyarakat dalam \\
pengembangan daya tarik \\
wisata (W2, W3, W4, W5, \\
W6, W7, O1, T1)
\end{tabular} & $\begin{array}{l}\text { Srategi WO } \\
\text { 1. Manfaatkan dukungan pemerintah } \\
\text { kabupaten dan masyarakat untuk } \\
\text { meningkatkan mutu obyek wisata } \\
\text { (W1, W2, W3, W4, W5) } \\
\text { 2. Jalin kerjasama dengan pelaku bisnis } \\
\text { di bidang pemasaran (promosi) dan } \\
\text { transportasi (W3, W4) } \\
\text { 3. Peningkatan kemampuan masyara- } \\
\text { kat dengan mengadakan pelatihan } \\
\text { di bidang pariwisata (W1, O1, O4) } \\
\text { 4. Pemberadayaan masyarakat untuk } \\
\text { berwirausaha hasil olahan produk } \\
\text { perikanan dan cendramata (O2,W3) }\end{array}$ \\
\hline $\begin{array}{l}\text { Threat }(\mathrm{T}) \text { / Ancaman } \\
\text { - } \\
\text { Terdapat tempat wisata lain yang } \\
\text { menjadi pesaing } \\
\text { - } \\
\text { Pencemaran lingkungan dengan } \\
\text { sampah bungkusan plastik makanan } \\
\text { dibuang di sembarang tempat } \\
\text { - } \\
\text { Mudah masuk aliran sesat dan } \\
\text { budaya asing } \\
\text { - }\end{array}$ & $\begin{array}{l}\text { Strategi ST } \\
\text { 1. } \text { Meningkatkan kesadaran } \\
\text { masyarakat tentang man- } \\
\text { faat obyek wisata }(\mathrm{T} 2, \mathrm{~T} 3, \mathrm{~T} 4) \\
\text { 2. } \\
\text { Perlu adanya pengelolaan } \\
\text { sampah yang terpadu di } \\
\text { Desa Namu, khususnya } \\
\text { dimasing-masing objek } \\
\text { wisata (W5, T2,) }\end{array}$ & $\begin{array}{l}\text { Strategi WT } \\
\text { 1. Meningkatkan mutu SDM dan } \\
\text { perbanyak fasilitas pendukung } \\
\text { pariwisata (W1, W3, W4, W6) }\end{array}$ \\
\hline
\end{tabular}

\section{DAFTAR PUSTAKA}

Darsana, I.W., I.M. Sendra, I.M. Adikampana, I.G. Mahagangga. 2017. Model Pengelolaan Wisata Bahari Berkelanjutan di Pulau Nusa Penida, Kecamatan Nusa Penida Kabupaten Klungkung, Bali. Jurnal Analisis Pariwisata, 17(1): 10-16.

Freddy, R. 2014. Analisis SWOT Teknik Pembeda Kasus Bisnis. Jakarta: PT Gramedia Pustaka Utama.

Hadiwijoyo, S.S. 2012. Perencanaan Pariwisata Perdesaan Berbasis Masyarakat, Yogyakarta: Graha Ilmu.

Riski, T.R. Azman, H.A. dan Rahmi F. 2016. Strategi Pengembangan Wisata Bahari di Kota Padang. Jurnal Manajemen dan Kewirausahaan, 7(1): 1-10.
Salim, H.L dan D. Purbani. 2015. Pengembangan Pariwisata Bahari Berbasis Masyarakat di Pulau Kaledupa, Kabupaten Wakatobi, Provinsi Sulawesi Tenggara. J. Manusia dan Lingkungan, 22(3): 380-387.

Suwena, I.K. 2010. Pengetahuan Dasar Ilmu Pariwisata. Denpasar: Udayana Press.

Soekadijo. 2001. Manajemen Kepariwisataan, Jakarta: PT. Gramedia Pustaka.

Undang-Undang No. 33 Tahun 2004. Prim-bangan Keuangan antara Pemerintah Pusan dengan Pemerintahan Daerah.

Undang-Undang RI No 23 Tahun 2014. Pemerintahan Daerah.

Yoeti, O. 1996. Pengantar Ilmu Pariwisata. Penerbit Angkasa. Bandung. 